\title{
The volcanic and mining geoheritage of San Pietro Island (Sulcis, Sardinia, Italy): the potential for geosites valorization
}

\author{
Gioncada, A. ${ }^{1}$, Pitzalis, E. ${ }^{1}$, Cioni, R. ${ }^{2}$, Fulignati, P. ${ }^{1}$, Lezzerini, M. ${ }^{1}$, Mundula, F. ${ }^{3}$, Funedda, A. ${ }^{3}$ \\ ${ }^{1}$ Dipartimento di Scienze della Terra, Univ. Pisa, Via S. Maria 53, 56126 Pisa \\ ${ }^{2}$ Dipartimento di Scienze della Terra, Univ. Firenze, Via La Pira 4, 50121 Firenze \\ ${ }^{3}$ Dipartimento di Scienze Chimiche e Geologiche, Univ. Cagliari, Cittadella Universitaria SS 554, \\ 09042 Monserrato (CA) \\ Corresponding author: Anna Gioncada phone +392215700, anna.gioncada@unipi.it
}

\section{Abstract}

Spectacular volcanic landforms characterize the Miocene lava flows and ignimbrites forming San Pietro Island (Sardinia, Italy). The island, furthermore, is a site of volcanic-hosted manganese mineralizations, which have been exploited until the past century. These geological features, set in a fascinating landscape context, represent a volcanic and mining geoheritage which could be valorized in terms of sustainable geotourism and scientific outreach.

In this paper, we examine potential sites of volcanological and mining geoheritage interest of San Pietro Island, some of which are part of the Italian Geosite Inventory. We update the scientific description of geological features according to the most recent research results, because we consider that a geosite description should evolve along with the development of scientific understanding. Also, we present some new potential geosites, with a discussion of their scientific relevance and geotouristic potential.

Three geo-volcanological features are identified: the spectacular megafolding structures of the comenditic lava flows; some peculiar and uncommon degassing features of ignimbrites; the volcanic-hosted manganese mineralizations and the related mining heritage. Based on this, four geosites are proposed and described: Becco Nasca (lava flow folding); Cala Fico (lava flow folding and mining heritage); La Punta (degassing features of ignimbrites); La Piramide (mining heritage). Some actions are suggested to promote the valorization of the geological and mining features of these geosites for geotourism and scientific outreach, and to raise awareness of these geoheritage values among the general public. 
Keywords: geosite, Sardinia, volcanic geoheritage, mining geoheritage, geotourism

\section{Introduction}

The last two decades have seen a significant surge in the interest in geoheritage, geoconservation, and geotourism studies worldwide, and tourism located around geological features is becoming an important tool to generate economic growth in many areas (e.g. Brocx and Semeniuk 2007; Dowling 2011). According to Cook and Abbot (2015), geoheritage can be considered as a link between natural phenomena and the human understanding of how Earth works. With this in mind, the study of the geoheritage value of potential geosites (i.e., geological settings with particular scientific, educational or touristic value, e.g., Wimbledon 1996), cannot overlook a rigorous scientific approach, besides taking into account the geoturistic, geoconservation, and geoeducational perspectives (Brilha 2018). This should result in an incisive disclosure, easy to understand and at the same time scientifically correct.

The study of mining geoheritage has been tackled since early '90, and many sites of ex-mining activities have already been declared World Heritage sites or Geoparks for their geological and mining values (i.e., Ezgebirge, Cabo de Gata, Iberian Pyrite Belt, Cerro Rico de Potosì; LopezGarcia et al. 2011; Horvath and Csullog 2012; Mata-Perellò et al. 2018). Conversely, volcano geoheritage research has been developing in the last few years (the earliest publications were published in 2010, see Nemeth et al. 2017a for a review). However, the fascinating processes of volcanism have rapidly generated particularly high interest to the general public (Erfurt-Cooper 2014). As a consequence, geoparks in areas characterized by recent volcanism or with active volcanoes are growing in popularity (Nemeth et al. 2017a and reference therein). On the other hand, it is interesting to note that recent studies have shown that volcanic geological sites provide opportunities to promote geotourism also in regions not directly associated with active volcanism (Harangi 2014; Migon and Pijet-Migon 2016; Szepesi et al. 2017). Several volcanic regions located in inactive volcanic areas are the type localities for special types of volcanic products, providing exceptionally good educational avenues for the dissemination of our current understanding on volcanism (Bitschene and Schueller 2011; Boivin and Thouret 2014; Bitschene 2015; Rapprich et al. 2017).

Within this framework, San Pietro Island (south-west Sardinia, Italy; Fig. 1a), hosting characteristic volcanic landforms of Late Miocene age and volcanic-hosted mineralizations exploited until the past century, represents an ideal site where evaluating the volcanic and mining geoheritage 
potentiality. The island is in fact characterized by a general fascinating landscape context and hosts several potential high value geosites (some of which are already present in the Italian Geosites Inventory; http://sgi.isprambiente.it/geositiweb/default.aspx), which deserve to be valorized through focused investigations. In this paper, we intend to shed light on the spectacular volcanic landforms of San Pietro Island and on its volcanic-hosted mining geoheritage, by updating the scientific description of existing geosites and describing new potential ones with a discussion of their scientific relevance and geotouristic potential. According to Moufti and Nemeth (2016), geosites are geological features with a specific origin, appearance, and geohistorical attribute, which alone, or in collaboration with other bioecological or anthropic elements, can become objects of geoheritage. We suggest here that the definition of a geosite should be interpreted as an outstanding outreach activity based on a deep knowledge of the general and local geological significance of the proposed site. For these reasons, a scientifically correct and complete, although clear and intelligible explanation of the processes implicated in the geosite generation should represent the first-order requisite for geosite proposal (Brilha 2016, 2018). A geosite should be considered for this reason a dynamic feature, whose description is prone to evolve by continuous upgrading in response to possible steps forward in the general knowledge of the geological processes they distill. Keeping in mind these concepts, three main features, of particular interest both by the geo-volcanological and geoheritage point of view, have been identified on San Pietro Island: the spectacular megafolding structures of the comenditic lava flows; some peculiar, uncommon degassing features of ignimbrites; the volcanic-hosted Mn mineralizations and the related mining heritage. Four geosites are described: Becco Nasca, Cala Fico, La Punta and La Piramide

\section{Geological context}

The present days Sardinia represents a small block of continental lithosphere, thick about 70 $\mathrm{km}$, between two large basins with stretched and thinned crust, undergoing partial oceanization in the last $18 \mathrm{Ma}$ : the Alghero-Provençal basin on the western side and the South Tyrrhenian basin on the eastern side. It is the result of the NNW-dipping subduction of Adria oceanic lithosphere below the European continental margin, during which magmatic products (the Sardinian Oligo-Miocene magmatic cycle, 32-15 Ma; Lustrino et al. 2013) were emplaced, following partial melting of the European asthenosphere induced by the subducting Adria plate. The result is a widespread volcanic arc formed on a continental crust.

The San Pietro Island belongs to the Sulcis Volcanic Province (SVP), located at the southwestern part of Sardinia and including also the Sant'Antioco Island and part of the Sulcis mainland (Cioni et al. 2001; Fig. 1). SVP represents the last manifestations of the Sardinian Oligo- 
Miocene magmatic cycle and is characterized by two phases: Old Phase (28.4-17.7 Ma), dominated by basaltic to intermediate lavas with subordinate pyroclastic products, with calcalkaline affinity; Young Phase (17.6-13.8 Ma), which was generated during the ending of the counter-clockwise rotation of the Sardinia-Corsica block away from South European margin, coeval with the opening of the Alghero-Provençal basin. SVP is characterized by eleven main ignimbrite sheets, ranging from trachytes to rhyolites in composition, with calcalkaline to peralkaline geochemistry (Morra et al., 1994; Cioni et al. 2001).

San Pietro Island is entirely formed by trachytic and rhyolitic (Fig. 2a) volcanic units of the most recent part of the Young Phase. Three main volcanic groups made up of several volcanic units are distinguished (Fig. 1a). The lowest is the Monte Sirai group, which mainly crops out in the central sector and whose most widespread volcanic unit is the Nuraxi rhyolite, a welded ignimbrite with a characteristic eutaxitic texture. Above the Monte Sirai group rests the Cala Lunga group, which represents the geological peculiarity of this island for the presence of mildly peralkaline lava flows and ignimbrites (comendites, Fig. 2b). In the Cala Lunga group a lower and upper parts can be distinguished. The lower part is an important comenditic complex mainly made up of several comenditic lava flows, generally identified with the different vents (Mt. Tortoriso, Becco di Nasca, P.ta Senoglio, Ventrischio, etc.). The upper part consists of rhyolitic ignimbrites that crop out in the northern sector of the island. The most common lithotypes are welded to scarcely welded ignimbrites hosting degassing structures. The Cala Lunga comenditic group is covered by the Le Colonne Group that crops out in the southern sector of the island and yet consists of alternating rhyolitic ignimbrites with different grade of welding. Both Le Colonne and Monte Sirai groups are related to a calcalkaline activity (Arana et al. 1974; Morra et al. 1994; Cioni et al. 2001). All these volcanic products were subaerially emplaced in a time span of about $1 \mathrm{Ma}$, starting from $15.8 \mathrm{Ma}$ (Pioli and Rosi 2005).

\section{The spectacular folds of the comenditic lava flows}

\section{Geosites: Becco Nasca (3909'38"N 8०15'01'E), Cala Fico $\left(3^{\circ} 9^{\circ} 09^{\prime} 22^{\prime \prime} \mathrm{N} 8^{\circ} 13^{\prime} 39^{\prime \prime} \mathrm{E}\right)$}

\section{General introduction to the geosites}

A lava is the result of magma effusion at the surface in a prevalently liquid state. An erupted lava flows down a slope under the action of gravity and, for a given slope angle, the velocity of its front is mainly function of magma rheology. The cooling of lava induces an increase of magma viscosity during flow; in fast flowing, low-viscosity basaltic lavas cooling mainly affects the upper surface, 
progressively forming a rigid crust under which still hot and fluid lava moves. The shear exerted by the flowing lava can induce plastic deformation of the overlying crust, forming the folds typical of the so-called ropy structures, or can stretch the crust to rupture, transforming the upper crust in a moving scoria bed. For this reason, after coming at rest the resulting product is a thin massive bed overlain by a plastically deformed upper layer or by a brittle, glassy scoria bed (respectively known as Pahoehoe and $A a$ lavas, two scientific terms derived from Hawaiian language). Silicic lava flows are instead less common, and, although their morphology has been described in several papers (e.g. Fink and Manley 1987; Branney et al. 2008), their emplacement has been directly observed only in few cases (e.g. Cordon Caulle 2013 eruption, Chile, Tuffen et al. 2013; Santiaguito 1999 eruption, Guatemala, Harris et al. 2004). These lava flows have very different features respect to their mafic counterparts described above, being generally much thicker (tens to hundreds of meters) and internally strongly structured, with thin foliations and folds (Fig. 3, 4a, b), ramp structures and morphologically marked levees. Their aspect can vary from glassy obsidian to lithic, crystal-rich, and their upper surface is always covered by subangular, variously vesicular blocks derived by the breakage during flow of the upper portion of the lava. an incredibly well-preserved and superbly well-exposed testimony of the latter type of lavas. These are rhyolitic, crystal-rich, mildly peralkaline lavas, characterized by the presence of abundant mmsized crystals of alkali feldspar (sanidine, Fig. 5) and quartz, and by very minor amounts of mafic minerals (biotite or Na-rich amphibole). The peculiar composition of these lavas was first described at the end of the XIX century by Bertolio (1895), who proposed the name Comenditi just from the type-locality of Le Commende, in the north-central part of the San Pietro Island (Fig. 1a). As a consequence, San Pietro Island assumes a particular geo-cultural heritage value since it hosts the type locality of comendite rocks, so valorizing not only the historical value related to the peculiar composition of these lava flows, but also their uncommon structure and morphology .

The peculiarity shown by the different outcrops of the comenditic lavas from San Pietro Island also lays in the quality of their exposition; in fact, they generally present an uncovered upper portion, resulting from a not very intense erosion that eventually interested only the breached, upper surface cover of the lava flows. Erosion also excavated the lateral, loose levee deposits of the flows exposing their flanks, in some cases up to the basal contact with the underlying deposits. The lava flows so unveil their internal structure, characterized by a thin foliation strongly deformed and folded during flow (Fig. 4a, b) which results in an apparent ropy structure of the upper surface, expressed as large ridge structures separated by furrows, clearly visible even from aerial or satellite images (Fig. 1b). Two main differences, however, distinguish these folded surfaces from the ropy 
structures typical of the pahoehoe lava flows: first, the wavelength of the deformation (i.e. the average distance between the ridges) varies in this case from metric to pluridecametric (Fig. 4c), differently from the centimetric spacing of basaltic ropes; second, the folds propagate throughout the entire thickness of the lava flows (in some cases up to $60 \mathrm{~m}$ ), while in basaltic pahoehoe lavas these only interest the crust, only few centimeters thick. These structures, suggested to be typical of crystal-rich silicic lavas, have been for the first time described and discussed just at San Pietro (Cioni and Funedda 2005), but can be however extended to other cases of similar compositional and textural features (Harris and Rowland 2015). These characters are clearly visible in particular at two sites in the San Pietro Island.

\section{Proposed geosite: the Becco Nasca lava flow}

A lava lobe with a clear internal folding expands northward from Becco Nasca to Punta Senoglio (Fig. 1a, b). The vent area possibly corresponds to a now dismantled domal structure, showing a clear concentric foliation. The lower part of the flow is exposed along Canale San Basilio, on the western flank of the lava (Fig. 6). The inner portion of the lava is nearly completely exposed for an approximate length of about $1500 \mathrm{~m}$, with a maximum thickness of about 70-80 $\mathrm{m}$. The folds wavelength decreases from the vent to the frontal area of the lobe, passing from an average value of $35 \mathrm{~m}$ to a value of 21 in the medial sector (Cioni and Funedda 2005). The frontal sector is partially covered by the following deposits of the Monte Ulmus Ignimbrite (Fig. 6), here constituting a small plateau. Where the ignimbrite is still preserved, the contact with the lava flow is characterized by the presence of a breccia facies composed by large obsidian blocks in a fine-grained glassy matrix, that possibly represent the original upper portion of the lava flow (Fig. 7). From the ignimbritic plateau of Punta Senoglio, a nice panoramic view is offered to the observer in the direction of the sea. Indeed, the quite complete absence of vegetation and the erosion conditions of the valley cutting Punta Senoglio allow the observation of geological relationships between the ignimbrites and the underlying lava flow. The light color of the lavas, contrasting with the blue and green hues of the sea and vegetation, and the megafold structures make a very characteristic landscape.

The megafold hinges of the lava flows (Fig. 4c) have curve traces in plain view (Fig. 1b and 6) because they are refolded during the flowing of lavas away from the vent, with a convexity in the sense of movement. These second phase folds are progressively much more closed toward the front. Minor, parasitic folding structures are scatteredly exposed along the lava flow, as pinch and swells structures (e.g. inside Canale San Basilio, Fig. 8) or metric-scale isoclinal folds with vertical axis. The frontal zone is well exposed in the area of Punta Senoglio, and it shows a different texture. In fact, in this zone the characteristic smooth, ridges and furrows morphology of proximal and medial 
zones of the flow abruptly changes, being here characterized by a rugged landscape with typical vertical foliations of the lava, fractures and ramps. Cioni and Funedda (2005) suggested that deformation of the lava flow proceeded incrementally from the vent to the front, progressively accumulating strain toward the frontal part, where deformation in many cases abruptly changes from ductile to fragile, with ramps developed along the axial plain of tight, partially recumbent folds of the first phase.

\section{Significance}

The outcrop is a very nice, probably unique example of a crystal-rich lava flow where, due to the differential erosion on the various zones of the flow (both vertically and laterally), it is possible to observe a large set of structures at different scale (from centimetric to decametric) (Cioni and Funedda 2005). From a scientific point of view, the site is highly significant on a world-scale basis, since it hosts the type locality of this type of lava flows and it offers, thanks to the very good preservation joined to the presence of deeply eroded portions, a really unique view of the different internal parts of a megafolded lava. As a consequence, the outcrop could become a reference for educational visits up to the college level and, due to the beauty and wilderness of the landscape, also for geotourism.

\section{Proposed geosite: the Cala Fico lava flows}

An interesting aspect of the internal structure of comenditic lava flows of San Pietro Island is well visible at Cala Fico, along the northwestern coast of the island (Fig. $1 \mathrm{a}, \mathrm{c}$ ). A thick, nearly vertical section of a lava flow is here well exposed just along the shore, on the right-hand side of the small bay. The outcrop possibly corresponds to the frontal part of a lava flow, resulting from the accumulation at the foot of a steep slope. The lava flow is here thickly foliated (Fig. 9a), and the original flow foliation is deformed into inclined to recumbent isoclinal folds arranged disharmonically, with a nearly horizontal axial plane. Lateral continuity of the folded limbs is often interrupted; locally, sheath folds are also present. The thinly spaced foliation is often evidenced by the presence of mm-thick coatings of black, dendritic Mn oxides (Fig. 9b), representing the remobilization of the $\mathrm{Mn}$ oxides that are abundant in the numerous fractures cutting the folds at high angle, where they often take a massive appearance.

\section{Significance}

The outcrop clearly shows the internal structure of the lava flow, that appears intensely and pervasively folded, and it is possibly representative of the frontal part of a lava flow, where 
accumulation of progressive deformation results in a strongly disharmonic arrangement of the folded surfaces. We suggest that it is also representative of the possible internal arrangement of structures close to the basal part of a folded lava flow, where internal folded surfaces can collapse under the load of the lava and are deformed during its final, gravity-driven movement (rheomorphic flow). This situation contrasts with the harmonic folding visible in the main body of the different flows of the island, where the clear ridge and through surficial structure suggests harmonic deformation defined by major folds with pluridecametric wavelength. Differently from the Becco Nasca, the frontal side of the Cala Fico lava flow deformed in a ductile way, possibly because emplacement time was short enough to prevent increasing of viscosity, which is caused by temperature decreasing, so brittle style of deformation was hampered.

\section{The degassing features of ignimbrites}

\section{Geosite: La Punta (39¹0'58'N $8^{\circ} 18^{\prime} 12^{\prime \prime}$ E)}

\section{General introduction to the geosite}

Pyroclastic density current (PDC) is a general term indicating a cloud of hot gases and particles that moves above the surface under the action of gravity, driven by the density difference with the surrounding atmosphere (e.g., Druitt 1998). The cloud can form by different processes, the most frequent being the collapse of an eruptive column, occurring when, dissipated the initial vertical momentum, the eruptive mixture maintains a density still greater than the atmosphere, and is so subjected to negative buoyancy forces. Deposition from these currents result in deposits with different characteristics, mainly dependent on the velocity of the current and its concentration. Ignimbrites represent a type of these deposits and have been associated to variably turbulent currents carrying a large number of pyroclastic fragments that are deposited from the basal, highly concentrated part of the cloud while flowing onto the surface (e.g. Branney and Kokelaar 1992). Ignimbrite deposits form under high sedimentation rates, so that the rapid accumulation of material does not allow a complete, immediate loss of gas from the fluidized, expanded moving bed that comes at rest. For this reason, ignimbrite deposits are often subjected to deflation and gas loss after deposition. In particular cases, ignimbrite deposits can be emplaced at a temperature higher than the glass transition temperature of the magma fragments (practically, the temperature at which the particles can be still considered molten respect to the characteristic time of deformation). In this case, the still plastic particles can agglutinate and weld after they come at contact in the deposits (Grunder and Russell 2005), so forming a continuous, welded material and losing the characteristics 
of clastic deposits (beds formed by separated particle with a large porosity). Rheology of welded ignimbrite is typically plastic, causing permanent deformation of the deposit by loading or following secondary movements under a shear stress (static or dynamic). Welding is a major cause of porosity and permeability decrease of the deposit; for this reason, deflation and gas loss from the deposit are hampered by the viscosity of the material, resulting in general flattening of the coarser particles and retardation in vertical gas migration. Gas released during deflation and compaction so can accumulate locally inside the deposits, forming large, dome-shaped cavities that can slowly migrate by buoyancy toward the upper part of the deposit until it remains plastic; expansion of these gas cavities occur by progressive gas accumulation and decompression related to their vertical migration (Mundula et al. 2013). Expansion also causes local compression in the host ignimbrite, and results in strong deflection and deformation of the deposit around these cavities.

Formation of these cavities is a really uncommon process, essentially due to the peculiar combination of the physical properties of the material in which they form (presence of abundant gas, appropriate viscosity and temperature, low permeability). As a matter of fact, such cavities, called blisters by analogy with similar structures quite common in basaltic pahoehoe lavas, have been up to now described or recognized in very few places worldwide (Fantale, Ethiopia: Gibson 1974; Guzzetta and Cinque 1983; Gran Canaria: Schmincke 1974) beside San Pietro Island, where wonderful exposures (Fig. 10) are present at La Punta locality, in the northwestern tip of the island (Fig. 1a and 1e). Such structures were called "Globoidi" by Taricco (1934), who described them together with alveolar and planar erosional features, without giving a genetic explanation. The structures have been also described by Di Gregorio et al. (2010), who misinterpreted them in terms of erosional structures. Recently, these structures have been suggested as a geosite in a project funded by local administration of San Pietro Island (http://carloforteonline.blogspot.com/2015/04/geositi.html), however still proposing the old interpretation of their origin. Similar structures have been also recently recognized in a different ignimbrite of the same period of activity on Sant'Antioco island (Mulas et al. 2013).

\section{Proposed geosite: La Punta}

Blisters in the La Punta area are visible in the Serra di Paringianu Ignimbrite, a compound ignimbrite constituted by a twin sequence of densely welded and partially welded flow units. In particular, they are confined to the upper half of the deposit, that here presents a total thickness up to about 30 meters (Mundula et al. 2013). Blisters are here represented by round cavities of variable diameter (from 5 up to about 20 meters) variably eroded (Fig. 10). Where completely preserved, blisters are lens-shaped in vertical cross-section, with a planar base and a convex upward roof. However, the roof of the blister often collapses or results eroded, and these structures are only 
partially preserved, with a clear circular base and remnants of the dome-shaped roof well evidenced by the deformed primary foliation of the ignimbrite.

No completely preserved blisters have been recognized in the La Punta area, and the original cavity is generally visible through the trend of the host rock foliation rimming the lower surface of the blister, or sporadically in vertical sections along the cliffs cut in the ignimbrite. Where still visible, horizontal vs. vertical dimension ratio ranges between 3 and 4. In a few cases, deeply argillified blocks from the collapsed vault of the cavity are still present at the base of the blister (Fig. 10b). The lateral portions of the blisters are intensely altered and show a strong argillification of the matrix glass, while foliation is deformed, reproducing the final domal shape of the blister. At least 30 blisters are present in the area of La Punta in about $1 \mathrm{~km}^{2}$ wide area (Mundula et al. 2013). The

\section{Significance}

Due to the rare occurrence of such type of structures, the very good preservation of the blisters in the La Punta area, and large number of them in a very small area, makes this locality a unique place where to observe and study these structures. Their perfect shape, also remarked by the deformed, thin-spaced foliation of the host ignimbrite encircling the entire blisters, can be also considered a very good example of natural oddity worth visiting by interested visitors.

\section{The volcanic-hosted Mn mineralizations and the mining heritage}

Geosites: La Piramide (3908'03"N 8०17'24'"E), Cala Fico $\left(3^{\circ} 9^{\circ} 09^{\prime} 22^{\prime \prime} \mathrm{N} 8^{\circ} 13^{\prime} 39^{\prime \prime} \mathrm{E}\right)$ 
Active volcanic environments represent favorable situations for fluid circulation in the upper crust, due to the presence of heat sources and of permeable rocks. Consequently, fossil volcanic environments are frequently the site of deposits of economic minerals, formed thanks to the capability of hydrothermal fluids to transport and concentrate ore metals (Pirajno 2009). At San Pietro, black veins and nodules of Mn-oxide minerals are commonly hosted in many of the lava and ignimbrite units. These volcanic-hosted $\mathrm{Mn}$ mineralization are of particular scientific relevance, because the genesis of similar Mn-oxide deposits in non-oceanic environment is still under discussion (e.g., Nicholson 1992; Roy 2006; Bau et al. 2014). As regards San Pietro, an origin of Mn oxides by hydrothermal fluids with a magmatic component (Sinisi et al. 2012) and a mixed hydrothermal-hydrogenetic origin by acidic, oxidizing fluids dominated by seawater (Pitzalis et al. 2019) can be taken into account. The Mn ore deposition occurred in a shallow water environment, as a result of the $\mathrm{pH}$ neutralization induced by water-rock interaction processes. Whichever the origin of the fluids, the thermal anomaly necessary to explain the circulation of the low temperature $\left(<100^{\circ} \mathrm{C}\right)$ fluids was probably linked to the late stages of volcanic activity that affected the area and may represent its last expression and witness.

Several of the Mn oxide mineralizations of San Pietro Island were considered economically exploitable in the past (Uras 1965). This is the case of Cala Fico, La Piramide, Capo Becco-Capo Rosso, Punta Nera-Le Lille mines, where Mn-oxide ores were mined until the 1970s, when the mining activity definitively ended. In these sites, besides the mineralized rocks, we can still observe abandoned mine gallery entrances and ruins of buildings and barracks, which represent an important fragment of the past Sardinian mining activity.

Between the mid-XIX and the opening of XX centuries, Carloforte, the main village of San Pietro Island, was a very important mining harbor, being the second harbor of Sardinia for number of ships and amount of transported material. Besides Mn oxides, the lead and zinc sulfide ores (mainly galena and sphalerite) coming from the nearby Sulcis-Iglesiente mines were, in fact, stored in Carloforte port warehouses, waiting to be carried to the Italian mainland (Sella 1871). The Carloforte sailormen involved in the transport of ore were typically called "Galanzieri", from the name of the lead sulfide mineral galena (locally called "galanza") they had to carry (https://www.carloforte.net/storia_galanzieri.htm). All these elements concur to constitute a mining heritage, still present in the collective memory of San Pietro inhabitants, that deserves to be valorized. According to Brilha (2016), the term 'mining heritage' can, in fact, be applied to whatever is involved in active and inactive mining exploration, such as minerals and rocks that are being or were extracted, industrial facilities, historical documentation of old mines, exploitation 
processes and techniques, and even mining communities' stories and traditions.

\section{Proposed geosites: La Piramide, Cala Fico}

La Piramide geosite (Fig. 1a, e) consists of a wide service apron excavated into two ignimbrite units, the Upper Comenditic Ignimbrite and the overlying Mt Ulmus ignimbrite (Fig. 11a). Evidence of the presence of Mn-oxide mineralization are the black veins and nodules, particularly abundant at the contact between the two ignimbrite units. The entrances of some old mine galleries and shafts, which are closed at present, are still visible on the cliff (Fig. 11a, b). Not far (about 200 m) from this area, there are ruins of some buildings (one of that was probably an old plant for ore treatment) that are part of the abandoned mine structures. The Cala Fico geosite is inserted in an amazing landscape with a spectacular overview on a small gulf on the Mediterranean Sea (Fig. 1a, c). The Mn-oxide mineralization occurs as veins and nodules within the above described comenditic lava flows (Fig. 11c, d). The entrances of some old mine galleries are still recognizable also at Cala Fico.

Cryptomelane, hollandite and minor pyrolusite are the main $\mathrm{Mn}$ oxide minerals forming the mineralization, accompanied by minor barite. They form nice textures, assuming botryoidal aspect, visible with a hand-lens within the open veins and nodules, and are often remobilized at the surface of the outcrop (Fig. 11d).

\section{Significance}

In our view, La Piramide and Cala Fico sites have the potential to be developed into high-value mining heritage geosites. While the above proposed geosites have geological peculiarities that are highly representative and nearly unique, the same cannot be said of the Mn oxide mineralizations, of which other examples exist around the world (Roy 2006 and reference therein). On the other hand, open-pit and underground mining sites have the potential to provide "windows" into the geological features hidden below the surface (Prosser 2018). In this view, the San Pietro mining site geoheritage can play an important role for scientific research and educational purposes.

Moreover, the mining heritage geosites may add cultural value for tourism in the San Pietro Island, analogously to other mining districts in Italy and in other part of the world (Lopez-Garcia et al. 2011; Conlin and Jolliffe 2011; Garofano and Govoni 2012; Wrede and Mugge-Bartolovic 2012). As a general consideration, abandoned mining sites have a high environmental and landscape impact, but may represent a potential source of income considering their possibility of being re-used as geoheritage and geotouristic resources after rehabilitation (Marescotti et al. 2018). Although mining regions are not expected to attract the same numbers of tourists as art heritage cities, there are tourists interested in visiting regions where, not long before, they would have been greeted by pit-head frames and ropeways (Horvat and Csullog 2012). 
Discussion

The process of geosite assessment and valorization for geotourism requires a large amount of crucial information to be collected and organized, to evaluate the options for successful and sustainable future developments. The inventory and assessment of geosites for geoheritage valorization has been the object of several works (e.g., Brilha 2016 and references therein), and some authors have proposed methods for a quantitative evaluation of geomorphosites (Reynard et al. 2007, 2016). Although a quantitative assessment of the San Pietro geosites is beyond the scope of the present work, the main features relevant for geoheritage evaluation purposes have been qualitatively considered (Table 1).

Table 1 represents a highly simplified version of the Reynard et al. (2016) methodology for geomorphosites assessment, adapted to the volcanic and mining heritage of San Pietro, and is meant as a preliminary reconnaissance scheme for a future quantitative assessment of the geoheritage potential of the island. The proposed geosites have a demonstrated scientific value, testified by the integrity, representativeness and rareness (probably uniqueness in the case of the lava flow megafolds and the ignimbrite degassing features) of the geological features (Table 1). This makes San Pietro a reference site for up to college-level didactic purposes, which may represent a lowimpact way of boosting geotourism. The amazing natural landscape adds to the aesthetic value of the geosites (Table 1). Concerning the visit conditions, more detailed surveys are required, in particular for evaluating the feasibility of visits to the mining structures. To our knowledge, of the several volcano-based geosites proposed up to now dealing also with silicic lava-dome structures or ignimbrites (Zangmo et al. 2017; Nemeth et al. 2017b; Nemeth and Mufti 2017) no structures similar to those described here for the San Pietro Island are present, so increasing the relevance of these geosites also on a world-wide scale.

The island of San Pietro is part of the Parco Geominerario Storico Ambientale della Sardegna. Some initiatives have been proposed by local institutions (e.g. Carloforte municipality) in the past, to promote geoturism and geosite valorization. For instance, a geo-touristic and geosite map in Italian is available online (https://ecosportellocarloforte.files.wordpress.com/2012/03/cartacarloforte-jpg-02-11-2010-2313-x-2353-1.jpg). However, the high value scientific and aesthetic peculiarities of the island described in this work would deserve further valorisation, taking into account an up-to-date scientific description and interpretation. Noteworthy, the non-resident affluence on the island in August has noticeably increased in the last years (from 45,021 people in 2016 to 61,078 in 2018, https://www.comunecarloforte.gov.it/content/news/flussi-e-grafici-relativi- 
al-mese-di-agosto), suggesting an increasing touristic appeal of the island. The development of new and sustainable volcanic and mining geoheritage touristic proposals could have a driving role to open a new way for tourism, and this could be achieved by a combination of delivering scientific information with entertainment (Szepesi et al. 2017 and reference therein). In this framework, some actions could be envisaged, planned, and implemented to promote the geological and mining features of these geosites and raise awareness of these geoheritage values among the general public: revision and improvement of geoeducation boards along the most frequented touristic trails; realization of field guides for professionals (students and researchers), documenting how to observe and interpret geological features (e.g., Marti et al. 2000) and other divulgative material (i.e., flyers) for the general public visiting the area, updated with the most recent scientific informations; evaluation of the feasibility to renovate some of the old mining buildings, which might host a small visitor centre, where the tourists could find information about the mining history of the area and where temporary exhibitions, focused on the outstanding geological and mineralogical features of the area, could be organized; re-opening and securing one of the mine galleries, suitable for carrying out guided tours; promoting the organization of a geotouristic tour of San Pietro island, taking into account the geo-volcanological history of the island. This could be done following the scientific thread represented by the volcanological evolution of San Pietro: this starts from the volcanic events (both effusive-lava flows and explosive-ignimbrites) that formed the rocks cropping out in the island, continues with the particular degassing structures ("blister") in the ignimbrite deposits, and arrives at the formation of the Mn-oxide mineralization, linked to the late thermal anomaly of the area. The scientific thread concludes with the historical exploitation of the $\mathrm{Mn}$ resources. Finally, but not last, the strong peculiarity and uniqueness of some of the proposed geosites could also be used to promote the visit to the island of university students and classes, that could be a good and low environmental impact resource for the island during the touristic low season.

\section{Conclusions}

In summary, San Pietro island, with its numerous viewpoints, fascinating abandoned mines and the superb exposed volcanic structures, of high scientific and aesthetic value, can provide geosites to be developed further for geotourism and scientific outreach. An efficient dissemination, freely accessible and, at the same time, scientifically correct, cannot avoid to be founded on a rigorous scientific approach applied to the study of geosites. We remark that a geosite description has to be a dynamic feature, evolving along with the development of scientific understanding. 
It is unavoidable that the uniqueness of some volcanic structures of the island must be warranted by the proper management of the proposed potential geosites and, more in general, of the whole San Pietro Island. The management must be finalized both to the geoconservation and to the promotion and development of a sustainable geotourism.

\section{Acknowledgments}

The authors are grateful to two anonymous reviewers for their comments and suggestions that helped to improve the quality of the manuscript, and to Kevin Page for editorial handling. Mario Bentivenga is warmly thanked for encouraging the submission of the manuscript.

\section{References}

Arana V, Barberi F, Santacroce R (1974) Some data on the comendite type area of S. Pietro and S. Antioco Islands, Sardinia. Bull Volcanol 38:725-736.

Bau M, Schmidt K, Koschinsky A, Hein JR, Usui A (2014) Discriminating between different genetic types of marine ferro-manganese crusts and nodules based on rare earth elements and yttrium. Chem Geol 381:1-9.

Bertolio, S., 1895, Sulle comenditi, nuovo tipo di rioliti a aegirina (nota preliminare): Rome, Rendiconti Reale Accademia dei Lincei, v. 4, p. 48-50.

Bitschene P, Schueller A (2011) Geo-education and geopark implementation in the Vulkaneifel European Geopark. GSA Field Guide 22:29-34

Bitschene PR (2015) Edutainment with basalt and volcanoes-the Rockeskyller Kopf example in the Westeifel volcanic field/Vulkaneifel European Geopark, Germany. Zeitschrift Der Deutschen Gesellschaft Fur Geowissenschaften 166(2):187-193

Boivin P, Thouret J-C (2014) The Volcanic Chaîne des Puys: A Unique Collection of Simple and Compound Monogenetic Edifices. In Fort M, André M-F (eds) Landscapes and Landforms of France. Springer, Dordrecht: 81-91

Branney MJ, Kokelaar BP (1992) A reappraisal of ignimbrite emplacement: progressive aggradation and changes from particulate to non particulate flow during emplacement of highgrade ignimbrite. Bull Volcanol 54:504-520.

Branney MJ, Bonnichsen B, Andrews GDM, Ellis B, Barry TL, McCurry M (2008) 'Snake River (SR)-type' volcanism at the Yellowstone hotspot track: distinctive products from unusual, hightemperature silicic super-eruptions. Bull Volcanol 70:293-314 
511 Brilha J (2016) Inventory and quantitative assessment of geosites and geodiversity sites: a review. Geoheritage 8:119-134

Brilha J (2018) Geoheritage: Inventories and Evaluation. In: Reynard E, Brilha J (eds) Geoheritage: Assessment, Protection, and Management. Elsevier, Amsterdam: 69-85

515 8 596 107 7218 519 520

Brocx M, Semeniuk V (2007) Geoheritage and geoconservation-history, definition, scope and scale. J Royal Soc of Western Australia 90:53-87

Cioni R, Funedda A (2005) Structural geology of crystal-rich, silicic lava flows: a case study from San Pietro Island (Sardinia, Italy). Geol Soc Am Spec Pap 396:1-14.

Cioni R, Salaro L, Pioli L (2001) The Cenozoic volcanism of S. Pietro Island (Sardinia, Italy). Rend. Sem. Facoltà Scienze Università Cagliari, Volume suppl 71(2):149-163.

Conlin MV, Jolliffe L (2011) Mining Heritage and Tourism: A Global Synthesis. Routledge. London, New York, pp 290.

Cook T, Abbott L (2015) Geoheritage: Preserving the Earth's Legacy: EARTH https://www.earthmagazine.org/article/geoheritagepreserving-earths-legacy

Di Gregorio F, Orru P, Piras G, Puliga G (2010) Note of the coastal and marine geomorphological map. Island of San Pietro (SW Sardinia). Scale 1:25.000. Boll AIC 138/2010:311-326

Dowling RK (2011) Geotourism's global growth. Geoheritage 3:1-1

Druitt TH (1998) Pyroclastic density currents, in: Gilbert JS \& Sparks RSJ (eds) The Physics of Explosive Volcanic Eruptions. Geol Soc London Special Publ 145:145-182.

Ellis BS, Wolff JA, Boroughs S, Mark DF, Starkel WA, Bonnichsen B (2013) Rhyolitic volcanism of the central Snake River Plain: a review. Bull Volcanol 75:745

Erfurt-Cooper P (2014) Volcanic Tourist Destinations, Volcanic Tourist Destinations. Springer Verlag, Berlin Heidelberg, pp 360

Fink JH, Manley CR (1987) Origin of pumiceous and glassy textures in rhyolite flows and domes. Geol Soc of America, Sp Paper 212: 77-88.

Garofano M, Govoni D (2012) Underground geotourism: a historic and economic overview of show caves and show mines in Italy. Geoheritage 4:79-92

Gibson IL (1974) Blister caves associated with an Ethiopian ash-flow tuff. Studies in Speleology 2:225-232.

Gisbert G, Gimeno D (2016) Ignimbrite correlation using whole-rock geochemistry: an example from the Sulcis (SW Sardinia, Italy). Geol Mag 154:740-756.

Gray JM (2013) Geodiversity: valuing and conserving abiotic nature, 2nd edn. John Wiley \& Sons, Chichester.

Grunder AL, Russell JK (2005) Welding processes in volcanology: insights from field, 
experimental, and modeling studies. J Volcanol Geoth Res 142:1-9.

Guzzetta G, Cinque A (1983) Le grotte a bolla del vulcano Fantale (Rift Etiopico). IV Symposium Internazionale di Vulcanospeleologia 12-17 settembre, Catania, pp. 45-51.

Harangi S (2014) Volcanic Heritage of the Carpathian-Pannonian Region in Eastern-Central Europe. In: Erfurt-Cooper P (ed) Volcanic Tourist Destinations, Volcanic Tourist Destinations, Springer Verlag, Berlin Heidelberg: 103-123

Harris AJ, Rowland SK (2015). Lava flows and rheology. In: "The Encyclopedia of Volcanoes" (Second Edition), pp. 321-342.

Harris AJL, Flynn LP, Matias O, Rose WI, Cornejo J (2004) The evolution of an active silicic lava flow field: an ETM+ perspective. J Volcanol Geoth Res 135:147-168.

Horvat G, Csullog G (2012) The role of ecotourism and geoheritage in the spatial development of former mining regions. In: Wirth P, Cernic Mali B, Fisher W (eds) Post Mining Regions in Central Europe, Problems, Potentials, Possibilities. Oekom, Munchen: 224-238.

Lopez-Garcia JA, Oyarzun R, López Andrés S, Manteca Martínez, JI (2011) Scientific, educational, and environmental considerations regarding mine sites and geoheritage: A perspective from SE Spain. Geoheritage 3:267-275

Lustrino M, Fedele L, Melluso L, Morra V, Ronga F, Geldmacher J, Duggen S, Agostini S, Cucciniello C, Franciosi L, Meisel T (2013) Origin and evolution of Cenozoic magmatism of Sardinia (Italy). A combined isotopic (Sr-Nd-Pb-O-Hf-Os) and petrological view. Lithos 180 $181: 138-158$

MacDonald R (1974) Nomenclature and petrochemistry of the peralkaline oversaturated extrusive rocks. Bull Volcanol 38:498-516.

Marescotti P, Brancucci G, Sasso G, Solimano M, Marin V, Muzio C, Salmona P (2018) Geoheritage values and environmental issues of derelict mines: examples from the sulfide mines of Gromolo and Petronio valleys (Eastern Liguria, Italy). Minerals 8(6):229

Martí J, Pujades A, Ferrés-Lopez D, Planagumà L, Mallarach-Carrera JM (2000) Volcanoes. A Field Guide to La Garrotxa Volcanic Zone; PNZVG: Olot, Spain.

Mata-Perellò J, Carrion P, Molina J, Villas-Boas R (2018) Chapter 9 - Geomining Heritage as a Tool to Promote the Social Development of Rural Communities. In: Reynard E, Brilha J (eds) Geoheritage: Assessment, Protection, and Management. Elsevier, Amsterdam: 167-177.

Migon P, Pijet-Migon E (2016) Overlooked geomorphological component of volcanic geoheritage diversity and perspectives for tourism industry, Pogrze Kaczawskie region, SW Poland. Geoheritage 8(4):333-350

Morra V, Secchi FA, Assorgia A (1994) Petrogenetic significance of peralkaline rocks from 
Cenozoic calc-alkaline volcanism from SW Sardinia, Italy. Chem Geol 118:109-142.

Moufti MR, Nemeth K (2016) Geoheritage of Volcanic Harrats in Saudi Arabia. Springer International Publishing AG Switzerland, pp 194

Mulas M, Mundula F, Cioni R (2013) Stratigraphy of the rheomorphic, densely welded, Monte Ulmus ignimbrite (SW Sardinia, Italy). Acta Vulcanol 23:17-26.

Mundula F, Cioni R, Mulas M (2013) Rheomorphic diapirs in densely welded ignimbrites: The Serra di Paringianu ignimbrite of Sardinia, Italy. J Volcanol Geoth Res 258:12-23

Németh K, Moufti M R (2017). Geoheritage values of a mature monogenetic volcanic field in intracontinental settings: Harrat Khaybar, Kingdom of Saudi Arabia. Geoheritage, 9:311-328.

Németh K, Casadevall T, Moufti MR, Marti J (2017a) Volcanic Geoheritage. Geoheritage 9:251254

Németh K, Wu J, Sun,C, Liu J (2017b) Update on the volcanic geoheritage values of the Pliocene to quaternary Arxan-Chaihe volcanic field, Inner Mongolia, China. Geoheritage, 9:279-297.

Nicholson K (1992) Contrasting mineralogical-geochemical signatures of manganese oxides: guides to metallogenesis. Econ Geol 87:1253-1264.

Pioli L, Rosi M (2005) Rheomorphic structures in a high-grade ignimbrite: the Nuraxi tuff, Sulcis volcanic district (SW Sardinia, Italy). J Volcanol Geoth Res 142:11-28

Pirajno F (2009) Hydrothermal Processes and Mineral Systems. Springer Netherlands, 1250 pp.

Pitzalis E, Fulignati P, Lezzerini M, Cioni R, Pinarelli L, Tamponi M, Gioncada A (2019) Origin of volcanic-hosted Mn-oxide mineralization from San Pietro Island (SW Sardinia, Italy): an integrated geochemical, isotopic and mineralogical study. J Geochem Expl in press.

Prosser CD (2018) Geoconservation, quarrying and mining: opportunities and challenges illustrated through working in partnership with the mineral extraction industry in England. Geoheritage $10: 259-270$

Rapprich K, Lisec M, Fiferna P, Zavada P (2017) Application of modern technologies in popularization of the Czech volcanic geoheritage. Geoheritage 9:413-420

Reynard E, Fontana G, Kozlik L, Scapozza C (2007) A method for assessing «scientific» and «additional values» of geomorphosites. Geograph Helv 62:148-158

Reynard E, Perret A, Bussard J, Grangier L, Martin S (2016) Integrated approach for the inventory and management of geomorphological heritage at the regional scale. Geoheritage 8:43-60

Roy S (2006) Sedimentary manganese metallogenesis in response to the evolution of the Earth system. Earth Sci Rev 77:273-305.

Schmincke HU (1974) Volcanological aspects of peralkaline silicic welded ash-flow tuffs. Bull Volcanol 38(2):594-636. 
Sella Q (1871) Sulle condizioni dell'industria mineraria nell'isola di Sardegna. Relazione alla Commissione Parlamentare d'inchiesta, Tip. Eredi Botta ed., Firenze, pp. 125, in italian.

Sinisi R, Mameli P, Mongelli G, Oggiano G (2012) Different Mn-ores in a continental arc setting: Geochemical and mineralogical evidences from Tertiary deposits of Sardinia (Italy). Ore Geol Rev 47:110-125.

Szepesi J, Harangi S, Esik Z, Novak TJ, Lukacs R, Soos I (2017) Volcanic geoheritage and geotourism perspectives in Hungary: a case of an UNESCO world heritage site, Tokaj wine region historic cultural landscape, Hungary. Geoheritage 9:329-349.

Taricco M (1934) Geologia del foglio Isola di San Pietro-Capo Sperone. Bollettino del R. Ufficio Geologico d'Italia 59:1-78.

Tuffen H, James MR, Castro JM, Schipper CI (2013) Exceptional mobility of an advancing rhyolitic obsidian flow at Cordon Caulle volcano in Chile. Nature Communications 4:1-7.

Uras I (1965) Depositi manganesiferi in Sardegna. Rend Ass Miner Sarda 70, n.3

Wimbledon WAP (1996) Geosites - a new conservation initiative. Episodes 19:87-88.

Wrede V, Mugge-Bartolovic, V (2012) GeoRoute Ruhr-A network of geotrails in the Ruhr Area National GeoPark, Germany. Geoheritage 4:109-114.

Zangmo GT, Kagou AD, Nkouathio DG, Gountié MD, Kamgang P (2017) The volcanic geoheritage of the Mount Bamenda calderas (Cameroon line): assessment for geotouristic and geoeducational purposes. Geoheritage 9(3):255-278.

\section{Table captions}

Table 1. Evaluation of the geoheritage and geotouristic significance of the proposed San Pietro geosites (adapted from Reynard et al. 2016).

\section{Figure captions}

Fig. 1 (a) Geological sketch map of San Pietro Island. Insets show location and satellite images of the four proposed geosites: (b) Becco Nasca - Punta Senoglio; (c) Cala Fico; (d) La Punta; (e) La Piramide. Le Commende, the type locality for comendite rocks, is indicated with a red asterisk.

Fig. 2 (a) Total alkali vs. $\mathrm{SiO}_{2}$ (TAS) diagram of the San Pietro volcanic rocks (gray field). Data from Lustrino et al. (2013) and Gisbert and Gimeno (2016). (b) Classification of the San Pietro 
island peralkaline volcanic products (gray field) using the $\mathrm{Al}_{2} \mathrm{O}_{3}$ vs. $\mathrm{FeO}_{\text {tot }}$ diagram of MacDonald (1974) for oversaturated peralkaline extrusive rocks. Data are taken from Gisbert and Gimeno (2016) and reference therein.

Fig. 3 Foliation in lava flow at San Pietro Island.

Fig. 4 (a, b) Examples of exposed folds in the Becco Nasca - Punta Senoglio comenditic lava flow; patterns indicate foliation and folds. (c) Panoramic view showing typical megafolds, with decametric wavelength, in the Becco Nasca - Punta Senoglio comenditic lava flow.

Fig. 5 A clear, well preserved, phenocryst of sanidine protruding from the groundmass. Note the typical light blue hue of the crystal.

Fig. 6 Geological map showing the relationship between the Becco Nasca-Punta Senoglio lava flows and the ignimbrites.

Fig. 7 Breccia facies of the upper portion of the Becco Nasca lava flow at the contact with the overlying Monte Ulmus ignimbrite.

Fig. 8 Example of pinch and swell structures in lava flow at San Pietro Island. The patterns highlight the structures.

Fig. 9 (a) Typical folds in the Cala Fico lava flows. (b) Folds in the Cala Fico lava flows evidenced by black Mn oxides marking the foliation.

Fig. 10 Typical examples of blisters in the La Punta area. The insert in Fig. 10a shows a view of the blisters in a Google Earth satellite image.

Fig. 11 (a) Panoramic view of La Piramide geosite. Note the entrances of some old mine galleries, partially obliterated by vegetation, at the contact between the Upper Comenditic Ignimbrite and the overlying Mt Ulmus ignimbrite units. (b) The entrance of one old mine gallery. (c) Folded lava crosscut by thin Mn oxide veins at Cala Fico geosite. (d) Typical example of Mn oxide mineralization within ignimbrite at La Piramide geosite. 
Table 1. Evaluation of the geoheritage and geotouristic significance of the proposed San Pietro geosites (adapted from Reinart et al. 2016).

\begin{tabular}{|c|c|c|c|c|c|}
\hline \multicolumn{2}{|l|}{ GEOSITE } & NASCA $^{\mathrm{a}}$ & CALA FICO $^{b}$ & LA PUNTA ${ }^{c}$ & $\begin{array}{c}\text { LA } \\
\text { PIRAMIDE }\end{array}$ \\
\hline \multicolumn{2}{|l|}{$\mathrm{LAT} / \mathrm{LONG}^{\mathrm{d}}$} & $\begin{array}{c}39^{\circ} 09^{\prime} 38^{\prime \prime} \mathrm{N} \\
8^{\circ} 15^{\prime} 01^{\prime \prime} \mathrm{E}\end{array}$ & $\begin{array}{l}39^{\circ} 09^{\prime} 22^{\prime \prime} \mathrm{N} \\
8^{\circ} 13^{\prime} 39^{\prime \prime} \mathrm{E}\end{array}$ & $\begin{array}{c}39^{\circ} 10^{\prime} 58^{\prime \prime} \mathrm{N} \\
8^{\circ} 18^{\prime} 12^{\prime \prime} \mathrm{E}\end{array}$ & $\begin{array}{c}39^{\circ} 08^{\prime} 03^{\prime \prime N} \\
8^{\circ} 17^{\prime} 24^{\prime \prime} \mathrm{E}\end{array}$ \\
\hline \multicolumn{2}{|l|}{ INTEREST } & Volcanic heritage & $\begin{array}{l}\text { Volcanic heritage, } \\
\text { mining heritage }\end{array}$ & $\begin{array}{l}\text { Volcanic } \\
\text { heritage }\end{array}$ & $\begin{array}{l}\text { Mining } \\
\text { heritage }\end{array}$ \\
\hline \multicolumn{2}{|l|}{ SIZE $\left(\mathrm{m}^{2}\right)$} & $6^{*} 10^{5}$ & $2 * 10^{5}$ & $1.3 * 10^{5}$ & $1 * 10^{3}$ \\
\hline \multicolumn{2}{|l|}{$\begin{array}{l}\text { SHORT } \\
\text { DESCRIPTION }\end{array}$} & $\begin{array}{l}\text { The megafolds of } \\
\text { the comenditic } \\
\text { lava flows }\end{array}$ & $\begin{array}{l}\text { The folds of the } \\
\text { comenditic lava } \\
\text { flows, Mn } \\
\text { mineralization and } \\
\text { abandoned mines }\end{array}$ & $\begin{array}{l}\text { The } \\
\text { degassing } \\
\text { features in } \\
\text { ignimbrite } \\
\text { ("blisters") }\end{array}$ & $\begin{array}{l}\text { Mn } \\
\text { mineralization } \\
\text { and abandoned } \\
\text { mines }\end{array}$ \\
\hline \multirow{3}{*}{ Scientific value } & Integrity & High & $\begin{array}{l}\text { Medium for mining } \\
\text { structures, high for } \\
\text { lava folds and ores }\end{array}$ & High & $\begin{array}{l}\text { Medium for } \\
\text { mining } \\
\text { structures, high } \\
\text { for ores }\end{array}$ \\
\hline & Representativeness & High & $\begin{array}{l}\text { High for mining } \\
\text { structures, high for } \\
\text { lava folds and ores }\end{array}$ & High & High for ores \\
\hline & Rareness & High & $\begin{array}{l}\text { Low for mining } \\
\text { structures, medium } \\
\text { for ores, high for } \\
\text { lava folds }\end{array}$ & High & $\begin{array}{l}\text { Medium for } \\
\text { ores }\end{array}$ \\
\hline \multirow{2}{*}{$\begin{array}{l}\text { Additional } \\
\text { value }\end{array}$} & Aesthetic value & High & $\begin{array}{l}\text { Medium for ores and } \\
\text { mining structures, } \\
\text { high for lava folds } \\
\text { and landscape }\end{array}$ & High & Low for ores \\
\hline & Cultural value & $\begin{array}{l}\text { Historical: type- } \\
\text { locality for } \\
\text { "comendite" }\end{array}$ & $\begin{array}{l}\text { Historical: } \\
\text { georesource supply }\end{array}$ & Low & $\begin{array}{l}\text { Historical: } \\
\text { georesource } \\
\text { supply }\end{array}$ \\
\hline \multirow[t]{2}{*}{ Education } & Education interest & $\begin{array}{l}\text { High (from non- } \\
\text { specialist up to } \\
\text { college) }\end{array}$ & $\begin{array}{l}\text { High (from non- } \\
\text { specialist up to } \\
\text { college) }\end{array}$ & $\begin{array}{l}\text { High (from } \\
\text { non-specialist } \\
\text { up to college) }\end{array}$ & $\begin{array}{l}\text { High (from } \\
\text { non-specialist } \\
\text { up to college) }\end{array}$ \\
\hline & $\begin{array}{l}\text { Interpretive } \\
\text { facilities }\end{array}$ & $\begin{array}{l}\text { Require } \\
\text { improvement }\end{array}$ & $\begin{array}{l}\text { Require } \\
\text { improvement }\end{array}$ & $\begin{array}{l}\text { Require } \\
\text { improvement }\end{array}$ & $\begin{array}{l}\text { Require } \\
\text { improvement }\end{array}$ \\
\hline
\end{tabular}

${ }^{a}$ geosite in the Italian Geosite Inventory as "colate comenditiche"; ${ }^{\text {b }}$ geosite in the Italian Geosite Inventory as "Cala Fico"; ${ }^{\mathrm{c}}$ the occurrence of diapirs (see text) adds geodiversity value to this geosite; ${ }^{\mathrm{d}}$ WGS84. Criteria of visit conditions (accessibility, safety and presence of tourism infrastructures), although relevant for geosite assessment, are not suggested here because they require a dedicated study, beyond the scope of this work. 


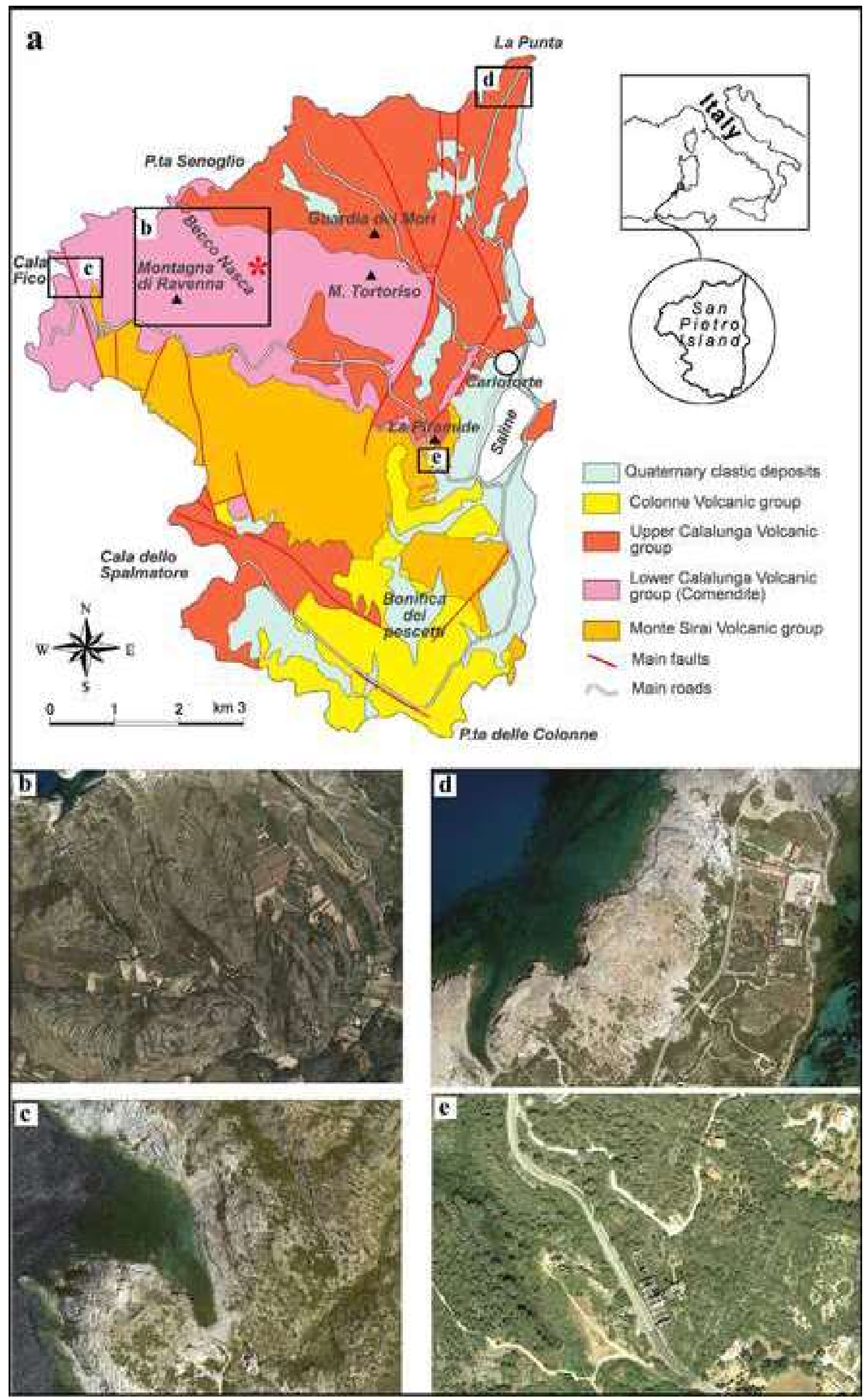



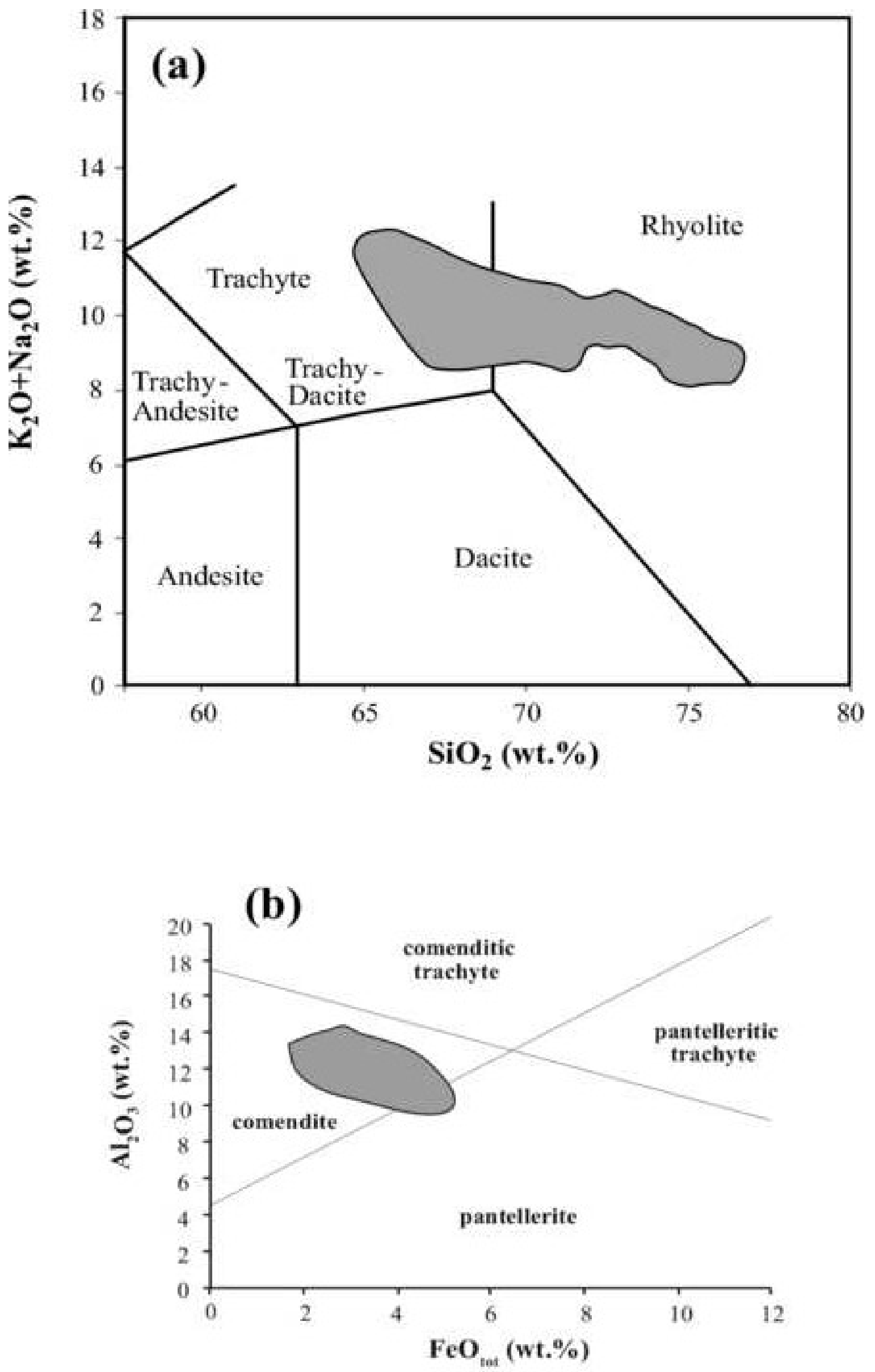


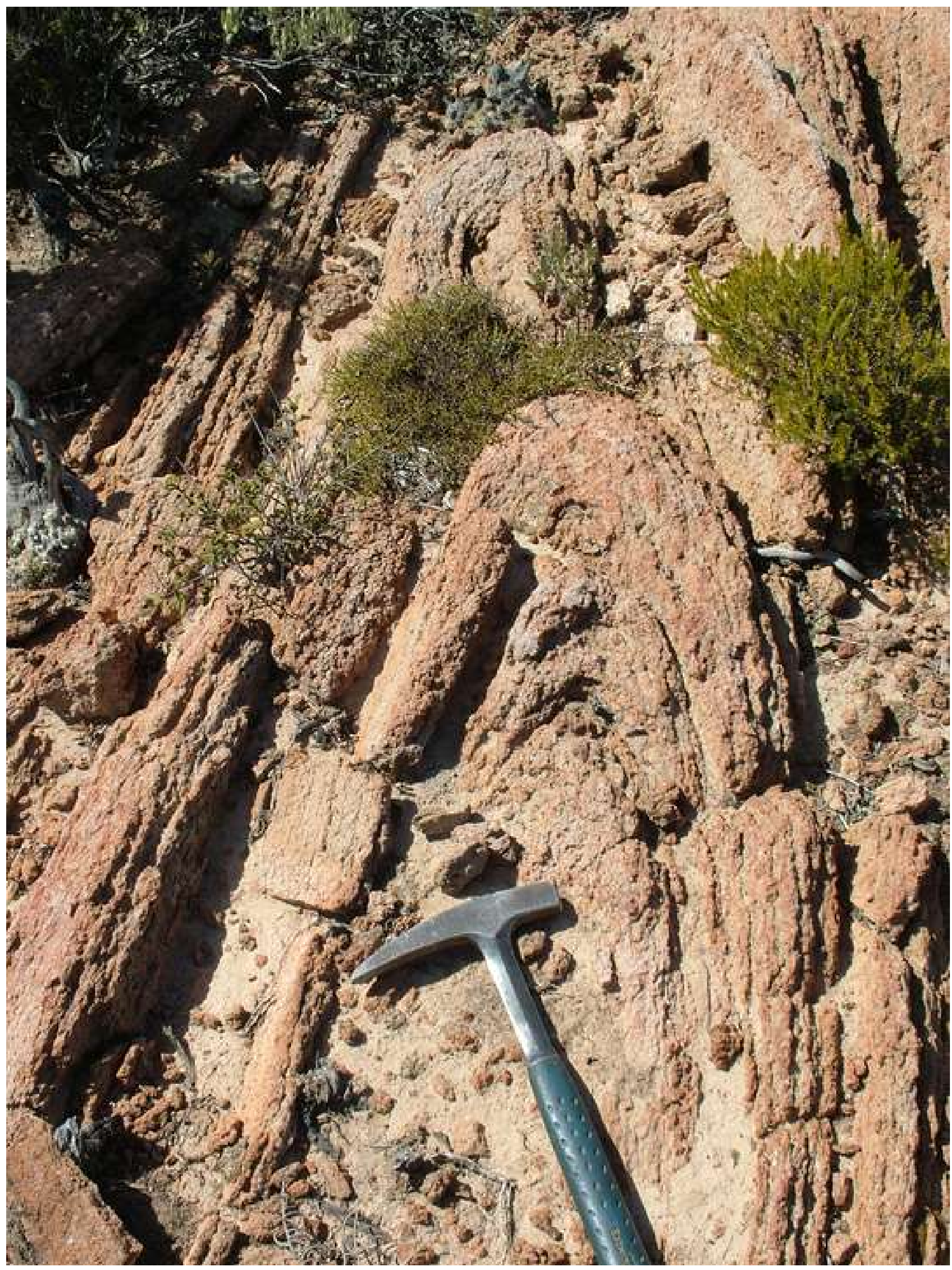



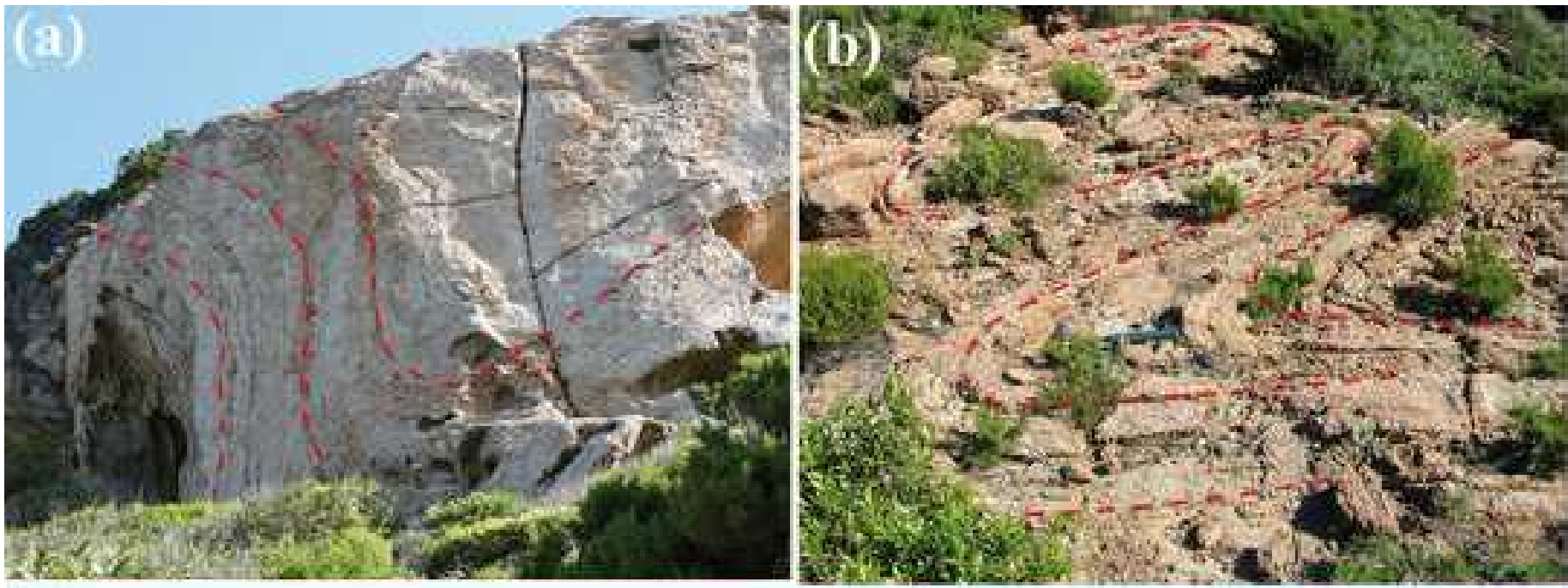

(c)

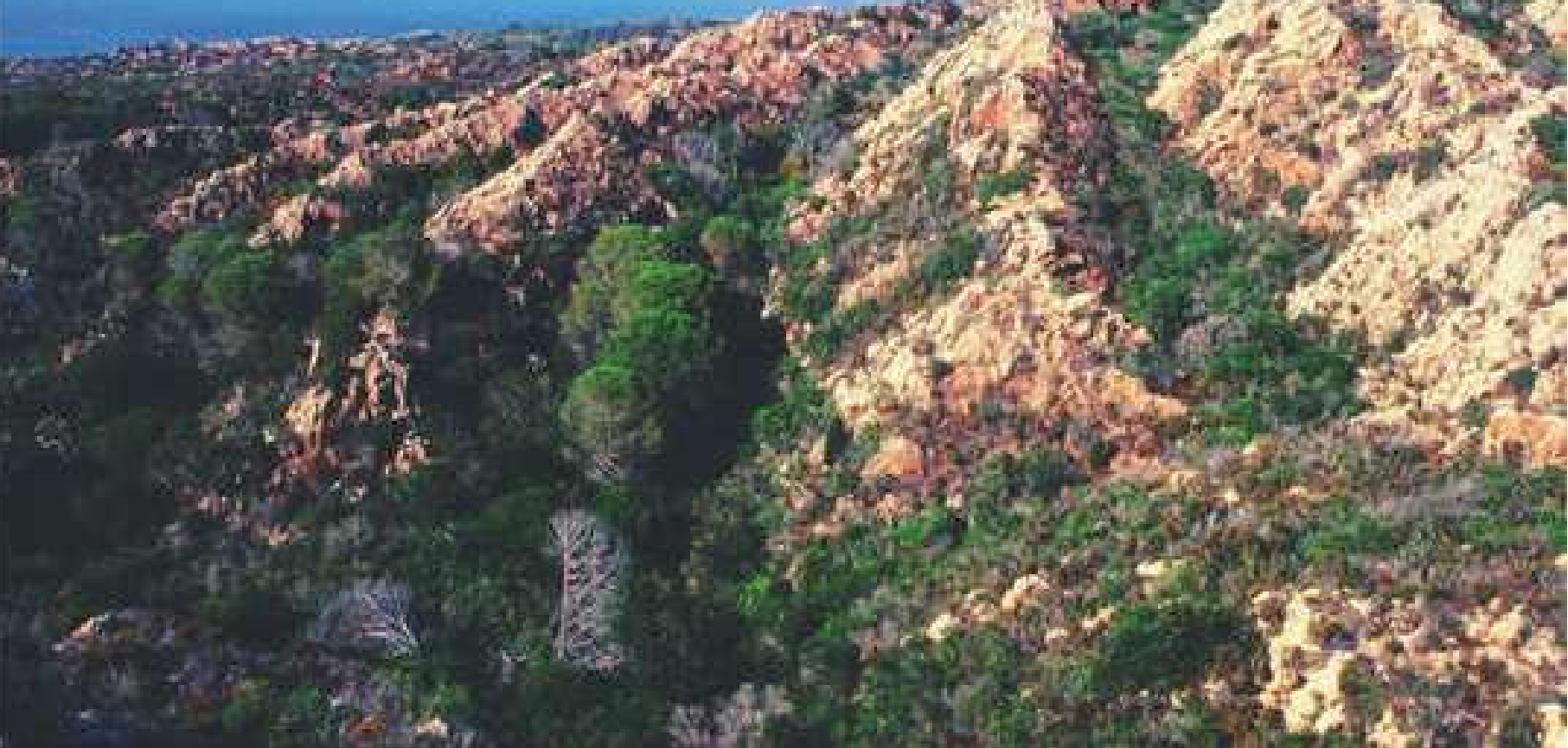




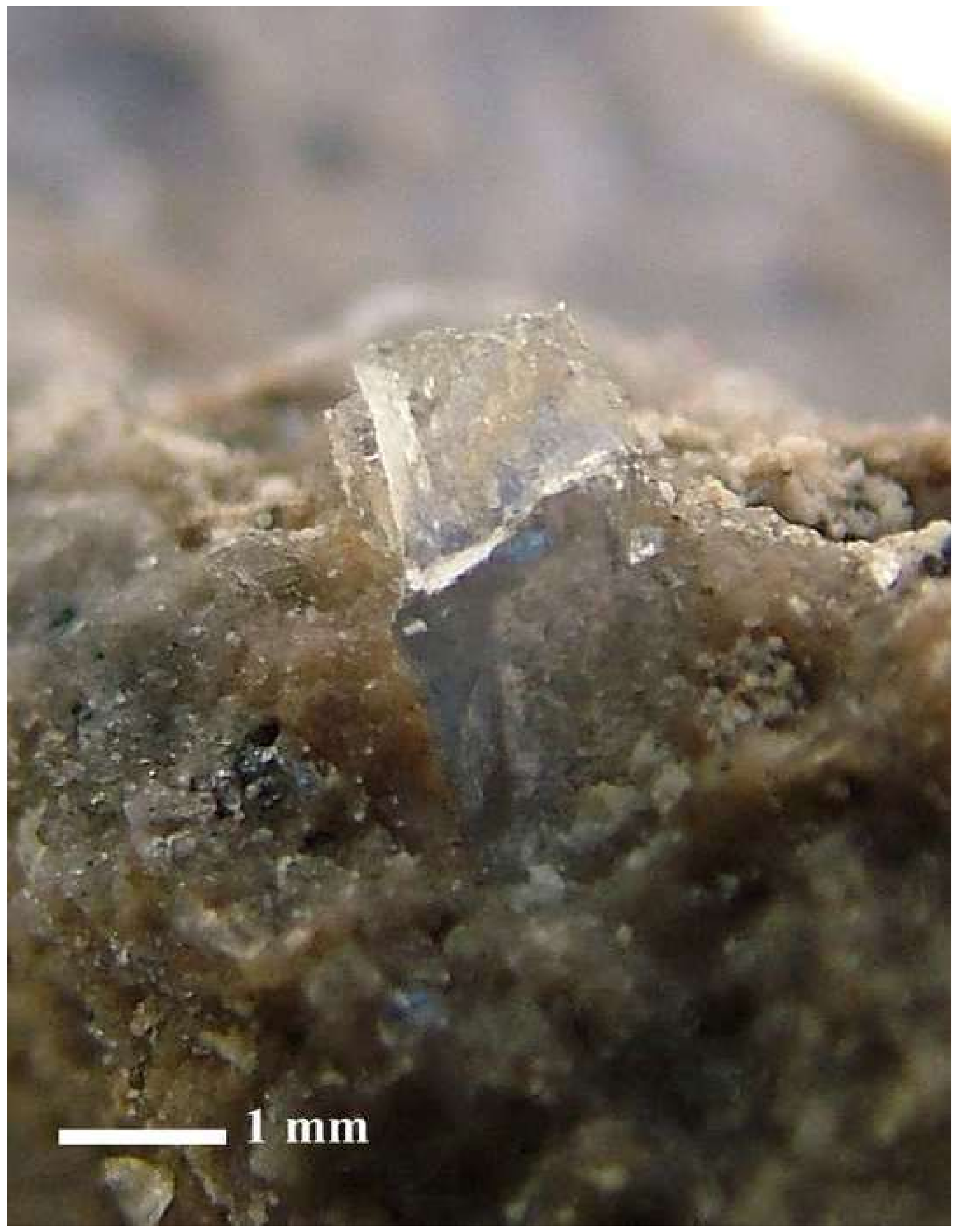




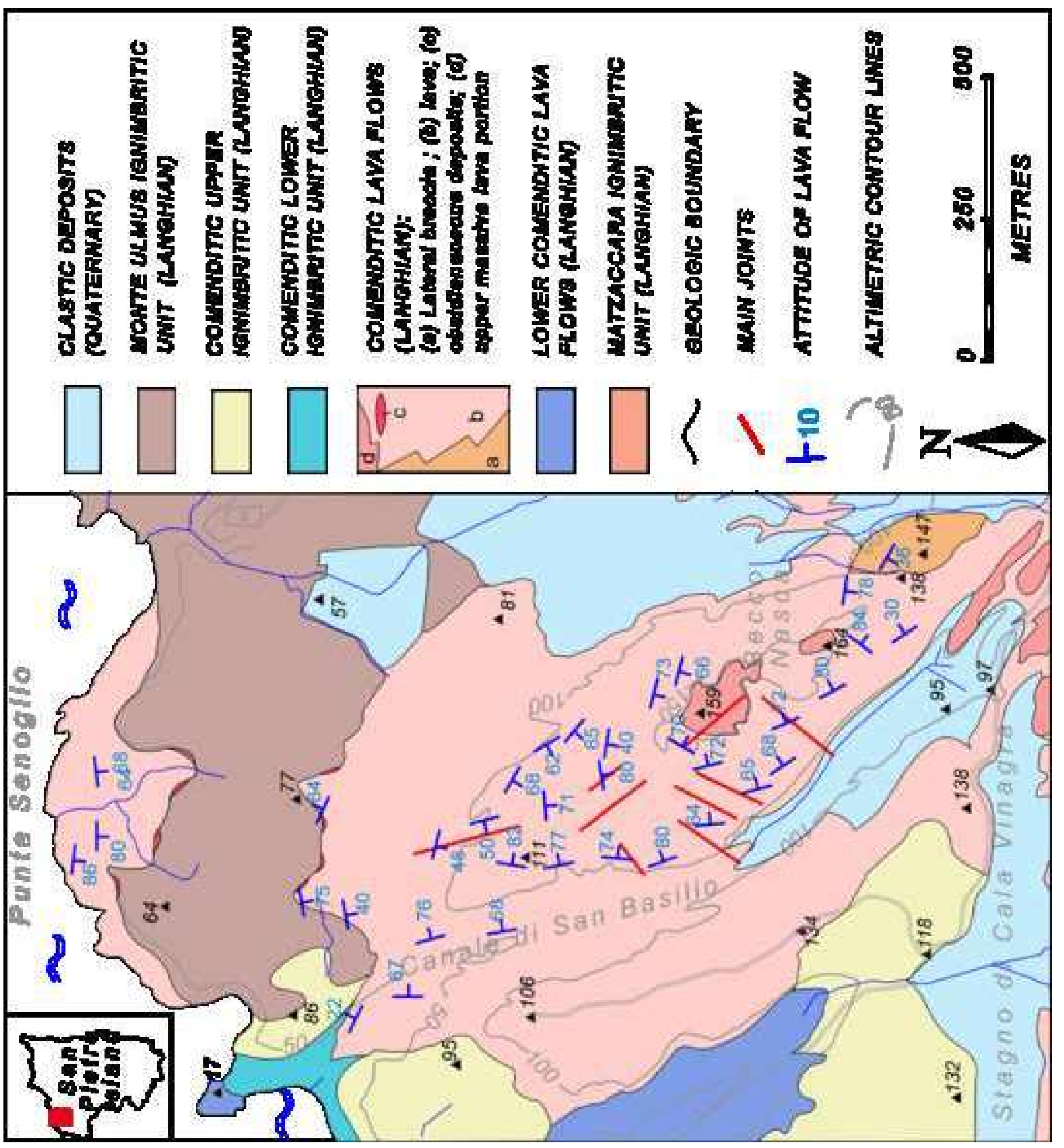




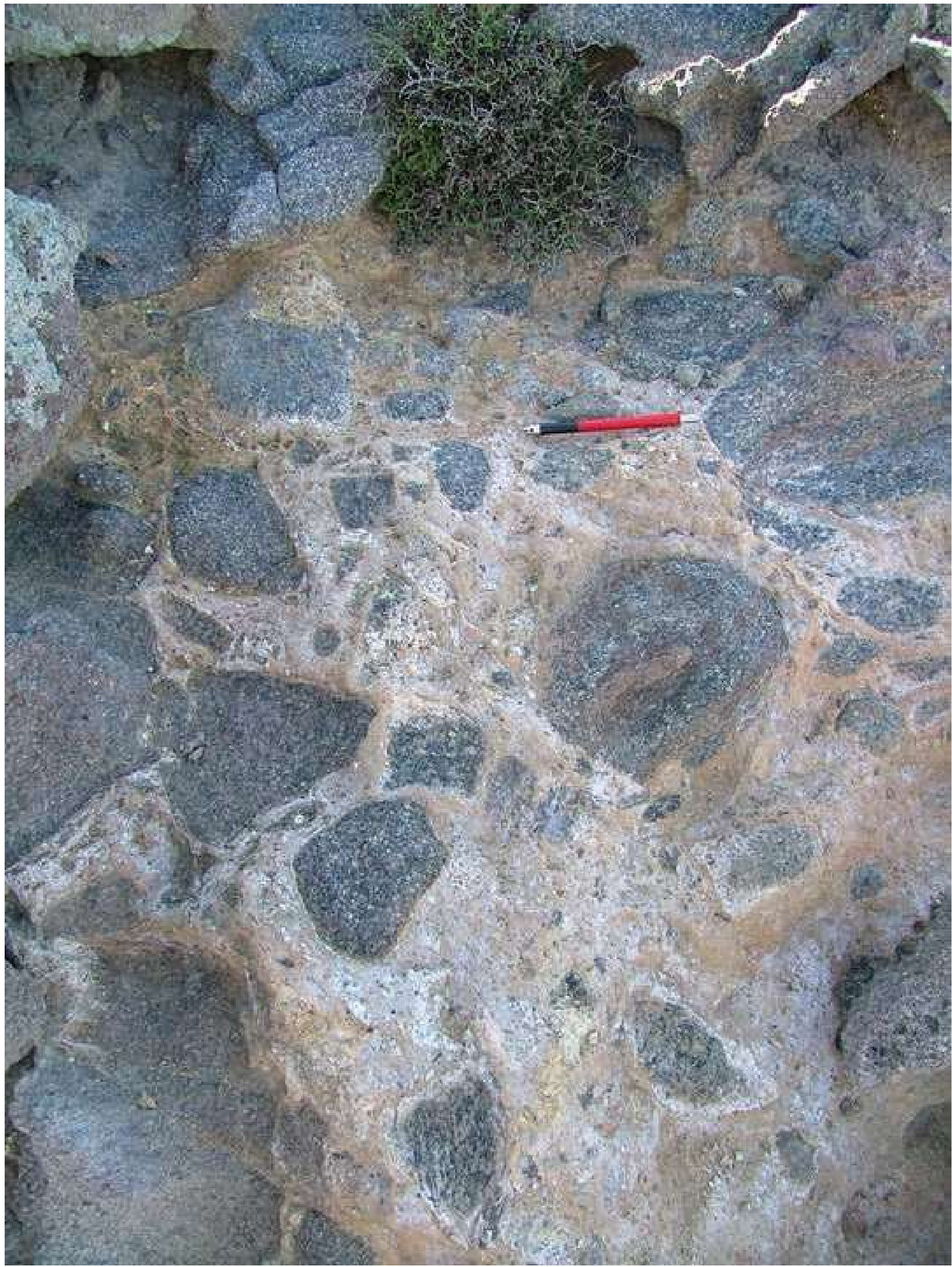




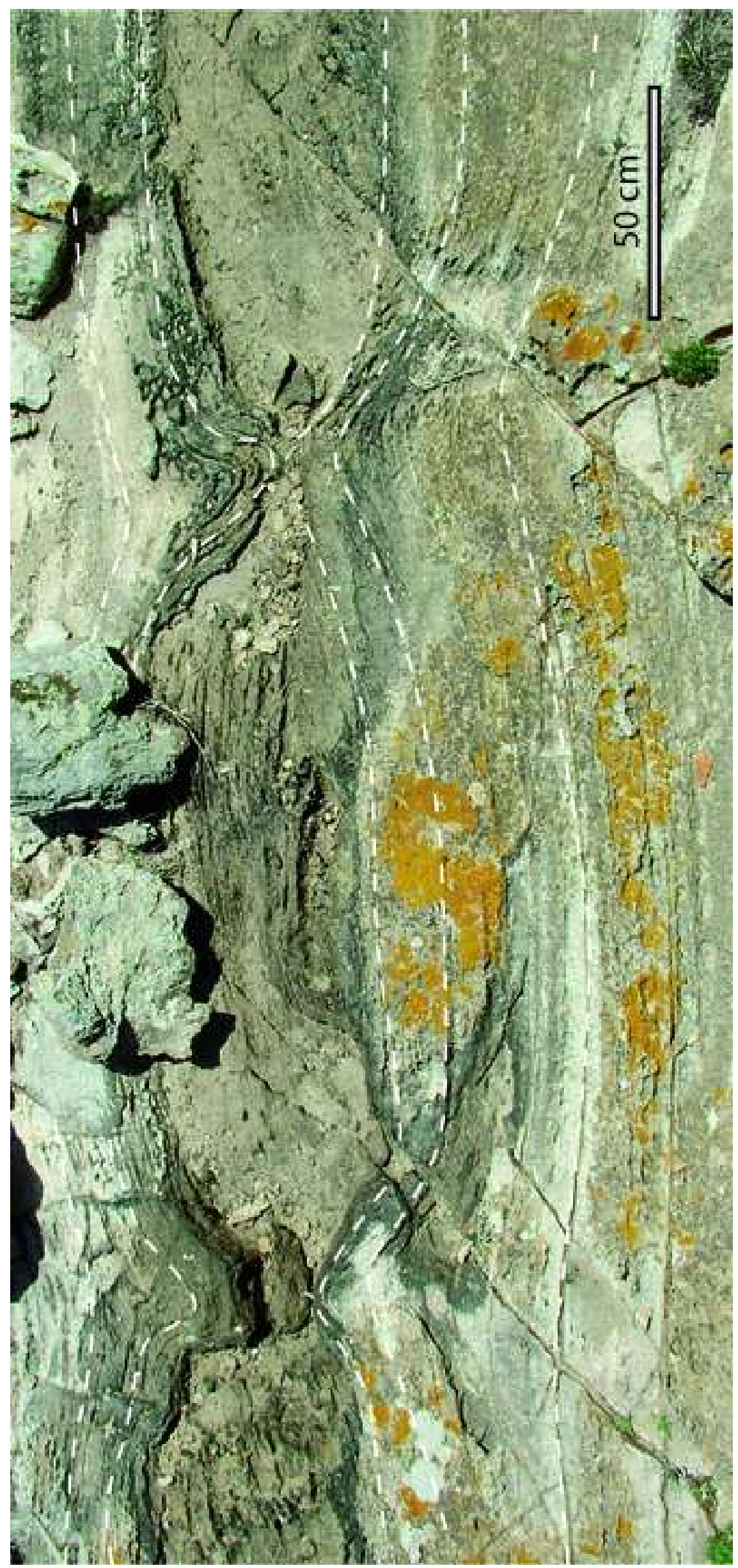

뭄 

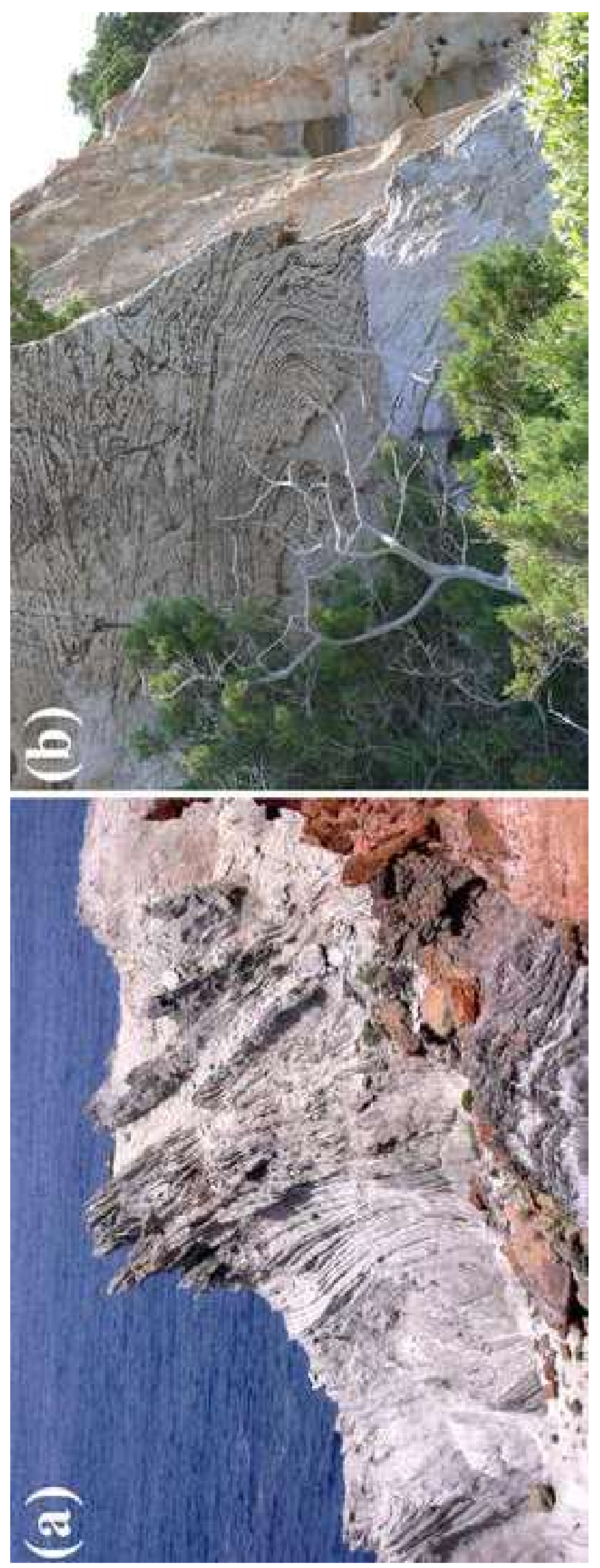

$\sigma_{1}$
$\frac{\Phi}{5}$
$\frac{\sigma}{2}$ 

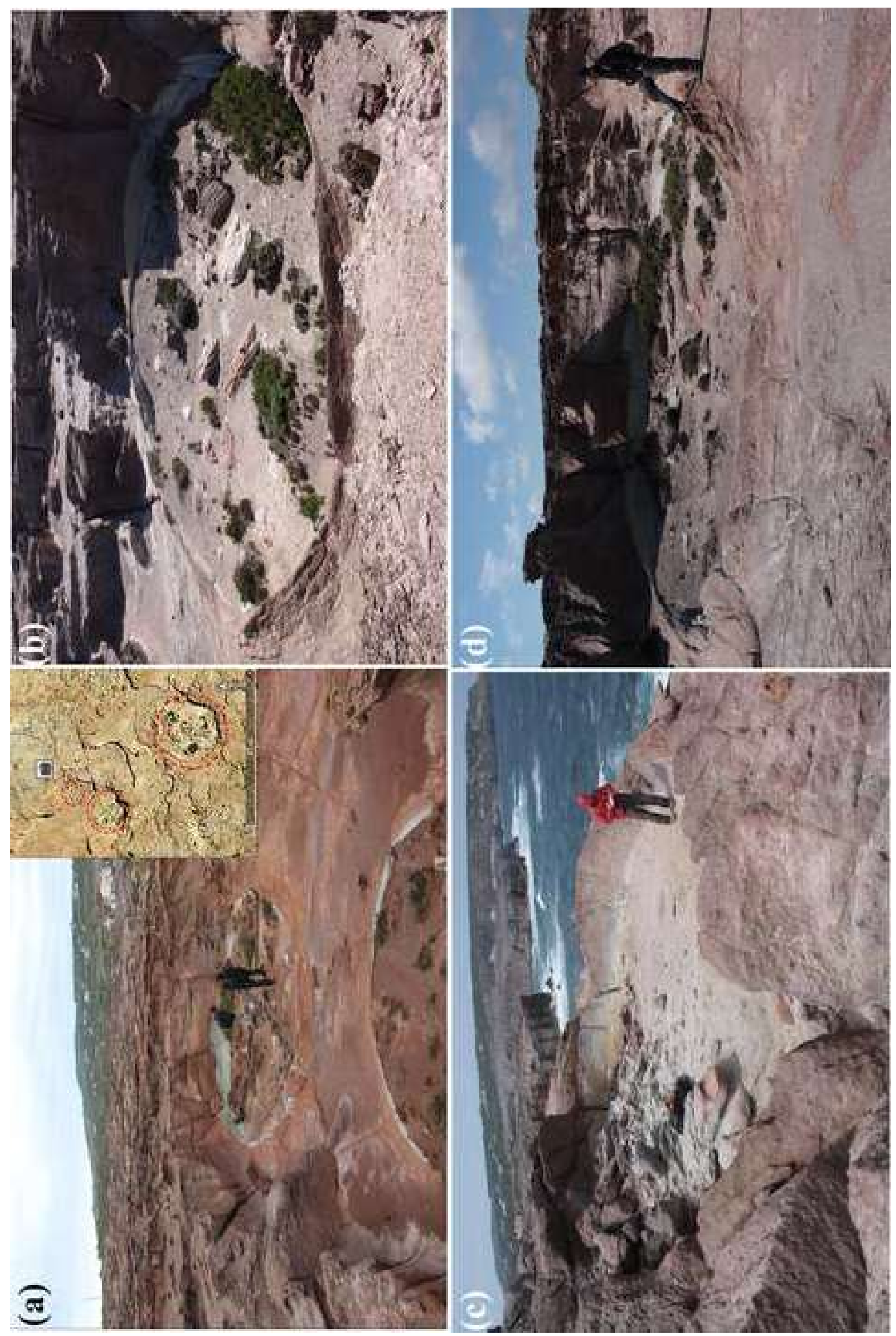

움

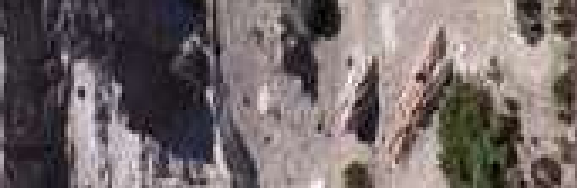

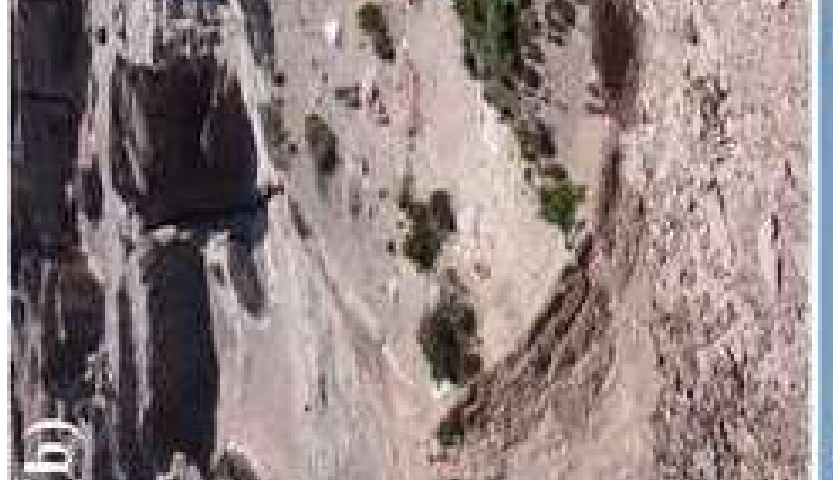


(a)

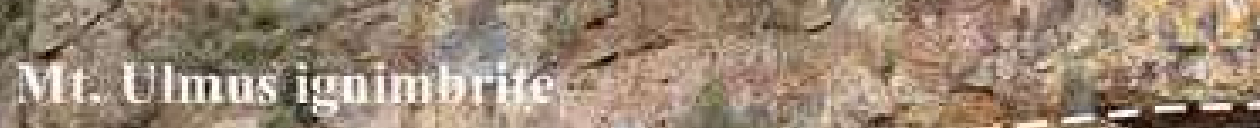
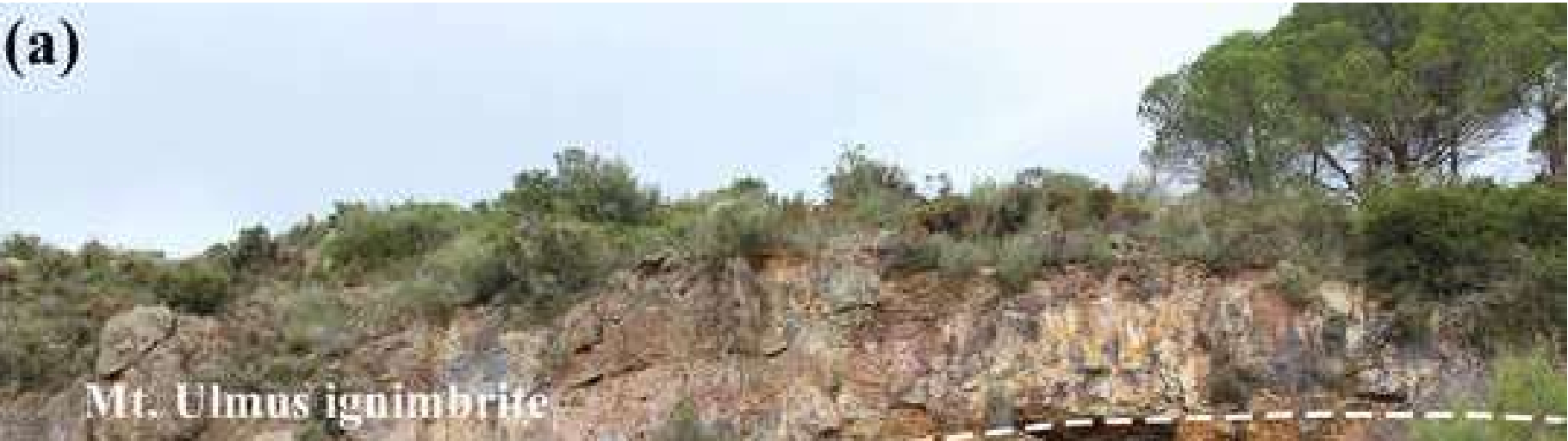

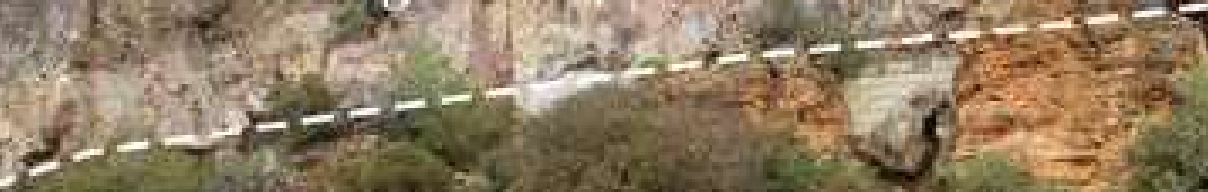

\section{Upper comenditic igmnimbrite}
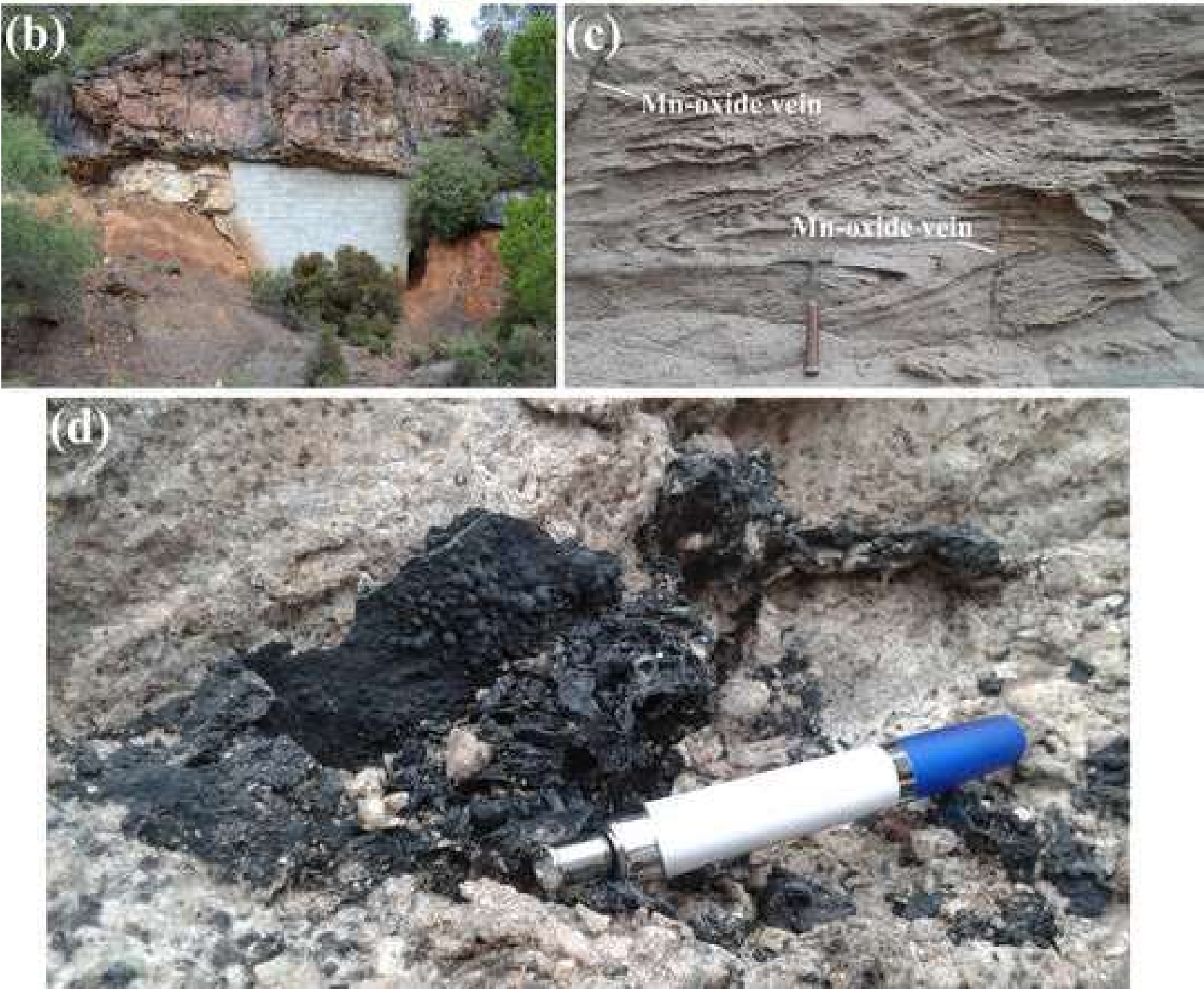